\title{
Vitamin C ameliorates tetrahydrocannabinol-induced spermatotoxicity in-vitro
}

\author{
Abdullateef Isiaka Alagbonsi ${ }^{1 *}$ [D and Luqman Aribidesi Olayaki ${ }^{2}$
}

\begin{abstract}
Background: We investigated the in-vitro effects of vitamin C on delta-9-tetrahydrocannabinol (THC) -induced reduction in spermatozoa motility and kinematics.

Methods: Six rats were used for the study. Semen from each of the 6 rats was randomly divided into 6 groups such that each rat's semen was in all of the groups. Groups I-III received placebo, THC (1 mM), and vitamin C (5 $\mathrm{mM}$ ) respectively. Group IV was pre-treated with cannabinoid receptors' blockers (CBs $\left.{ }^{-}\right) 1$ and 2, followed by THC. Groups $V$ and VI received THC and vitamin C, but group VI was additionally pre-treated with $\mathrm{CBs}^{-}$.

Results: The spermatozoa progressive motility, average path velocity (VAP), curvilinear velocity (VCL), straight-line velocity (VSL), amplitude of lateral head (ALH) and beat cross frequency (BCF) were reduced by THC (6.08 $\pm 1.16 \%$; $5.64 \pm 0.82 \mu \mathrm{m} / \mathrm{s} ; 6.96 \pm 0.74 \mu \mathrm{m} / \mathrm{s} ; 2.75 \pm 0.23 \mu \mathrm{m} / \mathrm{s} ; 0.31 \pm 0.02 \mu \mathrm{m}$; and $0.78 \pm 0.08 \mathrm{~Hz}$ respectively) but increased by vitamin C (51.20 $\pm 1.32 \% ; 17.90 \pm 0.21 \mu \mathrm{m} / \mathrm{s} ; 25.11 \pm 0.96 \mu \mathrm{m} / \mathrm{s} ; 8.80 \pm 0.27 \mu \mathrm{m} / \mathrm{s} ; 0.75 \pm 0.01 \mu \mathrm{m}$; and $3.15 \pm 0.03 \mathrm{~Hz}$ respectively) when compared to control $(39.72 \pm 0.38 \% ; 13.70 \pm 0.29 \mu \mathrm{m} / \mathrm{s} ; 18.04 \pm 0.58 \mu \mathrm{m} / \mathrm{s} ; 7.54 \pm 0.34 \mu \mathrm{m} / \mathrm{s}$; $0.65 \pm 0.02 \mu \mathrm{m}$; and $2.79 \pm 0.01 \mathrm{~Hz}$ respectively). Vitamin C inhibited the THC-induced reduction in these parameters $(37.36 \pm 0.73 \% ; 10.98 \pm 0.45 \mu \mathrm{m} / \mathrm{s} ; 13.58 \pm 0.30 \mu \mathrm{m} / \mathrm{s} ; 7.11 \pm 0.22 \mu \mathrm{m} / \mathrm{s} ; 0.58 \pm 0.01 \mu \mathrm{m}$; and $2.60 \pm 0.01 \mathrm{~Hz}$ respectively) in the absence of $\mathrm{CBs}^{-} 1$ and 2 , and even caused additional increases in progressive motility (49.54 $\left.\pm 1.01 \%\right)$, VAP $(15.70 \pm 0.38 \mu \mathrm{m} / \mathrm{s})$ and $\mathrm{VCL}(22.53 \pm 0.29 \mu \mathrm{m} / \mathrm{s})$ above the control levels with $\mathrm{CBs}^{-}$.
\end{abstract}

Conclusion: Vitamin C ameliorates the THC-induced reduction in spermatozoa motility in-vitro by modulation of their kinematics.

Keywords: Kinematics, Spermatozoa motility, Spermatotoxicity, Tetrahydrocannabinol, Vitamin C

\section{Background}

Marijuana, preparation of the flower, leaves and seeds of the plant Cannabis sativa (CS), is the most widely abused illicit drug worldwide [1] and is becoming globally legalised due to its medicinal use by patients with pain [2], inflammation [3], epilepsy [4], cancer [5], etc. However, its detrimental effects on male reproductive

\footnotetext{
* Correspondence: easylat@gmail.com

'Department of Physiology, School of Medicine and Pharmacy, University of Rwanda College of Medicine and Health Sciences, Huye, Republic of Rwanda Full list of author information is available at the end of the article
}

functions have been well-established. For instance, it decreases germ cell proliferation, reproductive organ weight [6,7], and semen parameters [7-9] by eliciting endocrine disruption, hyperprolactinaemia [10], downregulation of the hypothalamic-pituitary-gonadal axis $[10,11]$, and oxidative stress [9].

Delta-9-tetrahydrocannabinol (THC, an active psychoactive compound in CS), prescribed under the name Dronabinol (synthetic THC in sesame oil), is clinically being used for the treatment of acquired immunodeficiency syndrome (AIDS) -associated cachexia, multiple

(c) The Author(s). 2020 Open Access This article is licensed under a Creative Commons Attribution 4.0 International License, which permits use, sharing, adaptation, distribution and reproduction in any medium or format, as long as you give appropriate credit to the original author(s) and the source, provide a link to the Creative Commons licence, and indicate if changes were made. The images or other third party material in this article are included in the article's Creative Commons licence, unless indicated otherwise in a credit line to the material. If material is not included in the article's Creative Commons licence and your intended use is not permitted by statutory regulation or exceeds the permitted use, you will need to obtain permission directly from the copyright holder. To view a copy of this licence, visit http://creativecommons.org/licenses/by/4.0/ The Creative Commons Public Domain Dedication waiver (http://creativecommons.org/publicdomain/zero/1.0/) applies to the data made available in this article, unless otherwise stated in a credit line to the data. 
sclerosis, and cancer chemotherapy-associated nausea $[12,13]$. However, it has been consistently shown to negatively alter spermatozoa motility, swimming behaviour, and acrosome reaction in sea urchin [14-16], rat [17], and human [18, 19].

The effects of vitamin $\mathrm{C}$ on spermatozoa parameters and fertility rate in subfertile males remain controversial. For instance, its protective effect against testicular damage has been well-reported in different conditions [20, 21], while its toxic [20] and deoxyribonucleic acid (DNA)damaging $[22,23]$ potentials have also been shown.

We have previously observed in our in-vivo studies that vitamin $\mathrm{C}$ exacerbates the CS-induced gonadotoxicity, oxidative stress and reproductive hormonal toxicities, but these CS-induced toxicities were ameliorated only when vitamin $C$ was co-administered with melatonin $[7,9,10]$. In our very recent in-vitro study, we observed that melatonin alone ameliorated THC-induced spermatotoxicity by attenuating the THC-induced reduction of hyperactivated motility (HAM) in the capacitated spermatozoa [17]. The results of our recent in-vitro work [17] showed that melatonin alone attenuated, but did not abolish, the THC-induced reduction in spermatozoa motility and kinematics. This lack of abolishment is evident as the motility and kinematics were still significantly lower in spermatozoa that were treated with a combination of melatonin and THC than the control.

Vitamin $C$ has been reported to increase the motility and kinematics of caprine epididymal spermatozoa invitro [24]. Since the combination of melatonin and vitamin $C$ abolished the spermatotoxic effects of CS in-vivo, the lack of abolishment of the spermatotoxic effect of $\mathrm{THC}$ by melatonin alone in-vitro suggests that the effect of melatonin and vitamin $\mathrm{C}$ on the semen parameters might be additive or synergistic. This speculation led us to also investigate the effect of vitamin $\mathrm{C}$ on spermatozoa motility and kinematics in this study to clear our doubts whether vitamin $C$ contributed to the combined effect of melatonin and vitamin $\mathrm{C}$ or whether the combined effect is a result of melatonin only.

Following the procedures used in our previous in-vitro study, the present study investigated the effect of vitamin $\mathrm{C}$ on motility and kinematics of capacitated rat spermatozoa treated with cannabinoids using the computerassisted sperm analyser (CASA). We hypothesised that vitamin $\mathrm{C}$ will ameliorate the THC-induced reduction in spermatozoa motility and kinematics.

\section{Methods}

\section{Experimental protocol}

Six [6] male Wistar albino rats (200-210 g) sourced from the Department of Biochemistry's Animal House, University of Ilorin, Nigeria were housed at room temperature under the daily light/dark cycle with free access to food and water ad libitum. In addition to the study approval by the Ethics Committee of the University of Ilorin, the "Principles of laboratory animal care (NIH publication No. 85-23, revised 1985)" were followed.

Following the sacrifice of the rats with $0.8 \mathrm{ml} \mathrm{kg}^{-1}$ body weight of ketamine hydrochloride, the cauda epididymides were rapidly removed and minced in the modified Biggers-Whitten-Whittingham (BWW) capacitation medium, whose components have been previously described $[17,25]$. The liberated spermatozoa were incubated in the medium. Dimethyl sulphoxide (DMSO) was used to prepare the stock solution of the drugs, which was then diluted to the required concentration before each experiment in a BWW capacitation medium such that the final DMSO concentration was $0.2 \%(\mathrm{Vol} /$ Vol) [25] that does not affect spermatozoa motility [17].

Following the method of Charan and Kantharia [26] for the determination of animal sample size, semen from each rat $(n=6)$ was randomly divided into 6 treatment groups such that each rat's semen was in all of the groups as follows: Groups I-III were respectively treated with placebo (control mixture), THC (1 mM), and vitamin C $(5 \mathrm{mM})$. Group IV was pretreated with $1 \mathrm{mM}$ each of $\mathrm{CBs}^{-} 1$ (SR141716) and 2 (AM-630), followed by THC (1 mM). Groups V and VI were both treated with THC and vitamin C, but group VI was additionally pretreated with $1 \mathrm{mM}$ each of $\mathrm{CBs}^{-} 1$ (SR141716) and 2 (AM-630). Experiments were carried out by incubating spermatozoa in the BWW capacitation medium for 30 min. We generated dose-response and time-course of modulation curves from our preliminary experiment to arrive at the doses of $\mathrm{THC}$ and vitamin $\mathrm{C}$ and the duration used for the study while the same dose of THC was used for the $\mathrm{CBs}^{-}$[17].

\section{Determination of spermatozoa motility and kinematics} Spermatozoa progressive motility and kinematics (average-path velocity [VAP], curvilinear velocity [VCL], straight-line velocity [VSL], the amplitude of lateral head displacement $[\mathrm{ALH}]$, beat cross frequency $[\mathrm{BCF}]$, wobble, straightness, and linearity) were recorded with CASA (JH-6004 Sperm Quality Analyser, Jiangsu Jiahua Electronic Instrument Co., Ltd., Jiangsu, China) as previously described [17].

\section{Data analysis}

Data were blindly analysed using statistical software for the social sciences (SPSS) version 16.0 for Windows (IBM Corporation, Armonk, NY, USA). All values given were the Mean \pm S.E.M of the variables. The normality of the data was assessed using the Shapiro-Wilk test. Significance was assessed by the one-way analysis of variance (ANOVA), followed by a posthoc Tukey test for multiple comparisons. The five experimental groups 
were compared with the control group that received placebo, while groups that received cannabinoids with (out) vitamin $\mathrm{C}$ were additionally compared with THC group. Receiver Operating Characteristic (ROC) curve was used to examine the predictive abilities of spermatozoa kinematics on their progressive motility. The $p$-values of 0.05 or less were considered statistically significant.

\section{Results}

Dose-response and time-course of modulation of spermatozoa motility by tetrahydrocannabinol and vitamin $\mathrm{C}$ Throughout the observation period, $10 \mu \mathrm{M}, 100 \mu \mathrm{M}, 1 \mathrm{mM}$ and $10 \mathrm{mM}$ but not $1 \mu \mathrm{M}$ of THC reduced the rat spermatozoa motility when compared to the baseline (Fig. 1a).
On the contrary, $100 \mu \mathrm{M}, 1 \mathrm{mM}, 5 \mathrm{mM}$, and $10 \mathrm{mM}$ but not $10 \mu \mathrm{M}$ of vitamin $\mathrm{C}$ increased the rat spermatozoa motility when compared to the baseline (Fig. 1b).

\section{THC-induced reduction in progressive motility is} attenuated by vitamin $C$

THC reduced the spermatozoa progressive motility $(6.08 \pm 1.16 \%)$ when compared to the control $(39.72 \pm$ $0.38 \%$ ) but this reduction was inhibited by cannabinoid receptors 1 and 2 blockers $(41.38 \pm 0.36 \%)$. The progressive motility was increased by vitamin $C(51.20 \pm 1.32 \%)$ when compared to the control $(39.72 \pm 0.38 \%)$. Interestingly, vitamin $\mathrm{C}$ inhibited the THC-induced reduction in progressive motility $(37.76 \pm 0.73 \%)$, maintaining it at

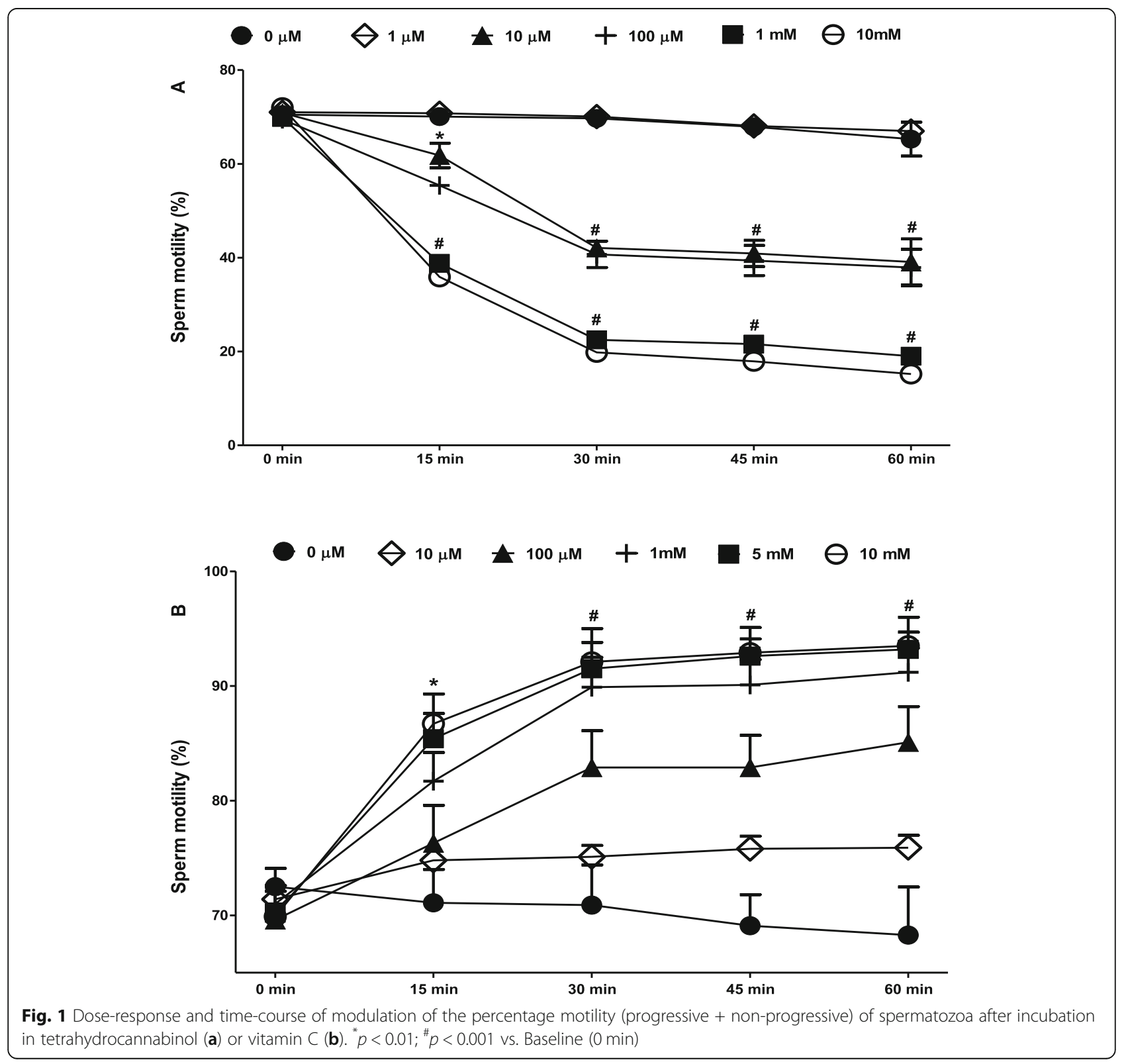


94\% of the control value. When cannabinoid receptors 1 and 2 were blocked, vitamin $C$ completely abolished the effect of THC on the progressive motility and even caused its additional increase $(49.54 \pm 1.01 \%)$ by $20 \%$ above the control level (Fig. 2).

THC-induced reductions in some spermatozoa kinematics are attenuated by vitamin $\mathrm{C}$

THC reduced the spermatozoa VAP $(5.64 \pm 0.82 \mu \mathrm{m} / \mathrm{s})$ when compared to the control $(13.70 \pm 0.29 \mu \mathrm{m} / \mathrm{s})$ but this reduction was inhibited by cannabinoid receptors 1 and 2 blockers $(14.70 \pm 0.76 \mu \mathrm{m} / \mathrm{s})$. The VAP was increased by vitamin $C(17.90 \pm 0.21 \mu \mathrm{m} / \mathrm{s})$ when compared to the control $(13.70 \pm 0.29 \mu \mathrm{m} / \mathrm{s})$. Moreover, vitamin $\mathrm{C}$ inhibited the THC-induced reduction in VAP $(10.98 \pm 0.45 \mu \mathrm{m} / \mathrm{s})$, maintaining it at $80 \%$ of the control. When cannabinoid receptors 1 and 2 were blocked, vitamin C completely abolished the effect of THC on VAP and even caused its additional increase $(15.7 \pm 0.38 \mu \mathrm{m} /$ s) by $13 \%$ above the control level (Fig. 3).

THC reduced the spermatozoa VCL $(6.96 \pm 0.74 \mu \mathrm{m} / \mathrm{s})$ when compared to the control $(18.04 \pm 0.58 \mu \mathrm{m} / \mathrm{s})$ but this reduction was inhibited by cannabinoid receptors 1 and 2 blockers $(21.39 \pm 0.73 \mu \mathrm{m} / \mathrm{s})$. The VCL was increased by vitamin $C(25.11 \pm 0.96 \mu \mathrm{m} / \mathrm{s})$ when compared to the control $(18.04 \pm 0.58 \mu \mathrm{m} / \mathrm{s})$. Furthermore, vitamin $\mathrm{C}$ inhibited the THC-induced reduction in VCL $(13.58 \pm 0.30 \mu \mathrm{m} / \mathrm{s})$ by maintaining it at $75 \%$ of the control value. When cannabinoid receptors 1 and 2 were blocked, vitamin $\mathrm{C}$ completely abolished the effect of THC on VCL and even caused its additional increase
$(22.53 \pm 0.29 \mu \mathrm{m} / \mathrm{s})$ by $20 \%$ above the control level (Fig. 4).

THC reduced the spermatozoa VSL $(2.75 \pm 0.23 \mu \mathrm{m} / \mathrm{s})$ when compared to the control $(7.54 \pm 0.34 \mu \mathrm{m} / \mathrm{s})$ but this reduction was inhibited by cannabinoid receptors 1 and 2 blockers $(6.86 \pm 0.47 \mu \mathrm{m} / \mathrm{s})$. The VSL was increased, albeit insignificant, by vitamin $C(8.80 \pm 0.27 \mu \mathrm{m} / \mathrm{s})$ when compared to the control $(7.54 \pm 0.34 \mu \mathrm{m} / \mathrm{s})$. Vitamin $C$ inhibited the THC-induced reduction in VSL $(7.11 \pm 0.22 \mu \mathrm{m} / \mathrm{s})$ by maintaining it at $94 \%$ of the control value. When cannabinoid receptors 1 and 2 were blocked, vitamin C completely abolished the effect of THC on VSL by maintaining it at a level $(7.86 \pm 0.17 \mu \mathrm{m} / \mathrm{s})$ comparable to that of the control (Fig. 5).

THC reduced the spermatozoa ALH $(0.31 \pm 0.02 \mu \mathrm{m})$ when compared to the control $(0.65 \pm 0.02 \mu \mathrm{m})$ but this reduction was inhibited by cannabinoid receptors 1 and 2 blockers $(0.69 \pm 0.00 \mu \mathrm{m})$. The VSL was increased by vitamin $C(0.75 \pm 0.01 \mu \mathrm{m})$ when compared to the control $(0.65 \pm 0.02 \mu \mathrm{m})$. Vitamin $\mathrm{C}$ inhibited the THCinduced reduction in ALH $(0.58 \pm 0.01 \mu \mathrm{m})$ by maintaining it at $89 \%$ of the control value. When cannabinoid receptors 1 and 2 were blocked, vitamin $\mathrm{C}$ completely abolished the effect of THC on ALH by maintaining it at a level $(0.67 \pm 0.01 \mu \mathrm{m})$ comparable to that of the control (Fig. 6).

THC reduced the spermatozoa BCF $(0.78 \pm 0.08 \mathrm{~Hz})$ when compared to the control $(2.79 \pm 0.01 \mathrm{~Hz})$ but this reduction was inhibited by cannabinoid receptors 1 and 2 blockers $(2.88 \pm 0.00 \mathrm{~Hz})$. The BCF was increased by vitamin $\mathrm{C}(3.15 \pm 0.03 \mathrm{~Hz})$ when compared to the

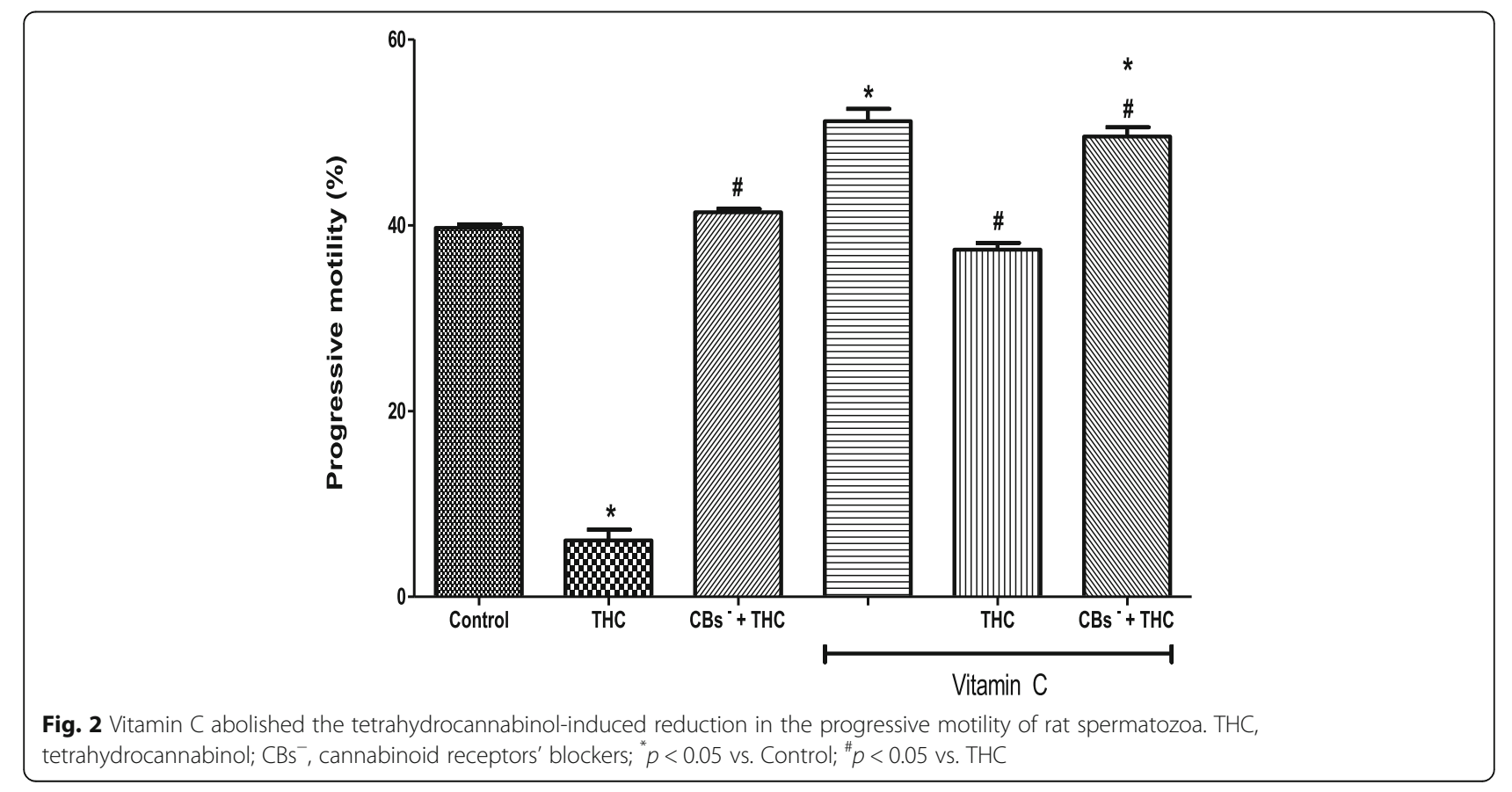




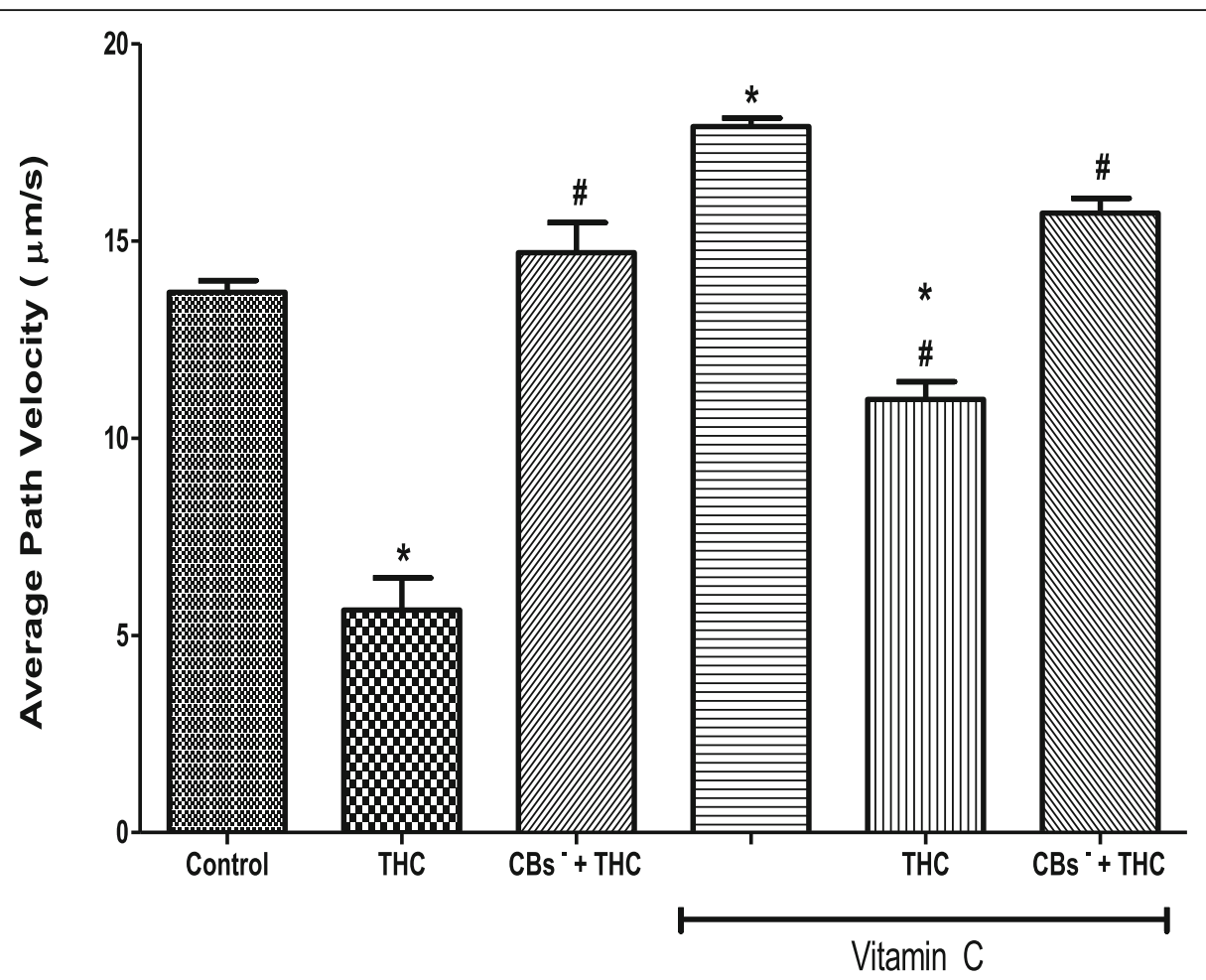

Fig. 3 Vitamin $C$ attenuated the tetrahydrocannabinol-induced reduction in the average path velocity of rat spermatozoa. THC, tetrahydrocannabinol; $\mathrm{CBs}^{-}$, cannabinoid receptors' blockers; ${ }^{*} p<0.05$ vs. Control; ${ }^{\#} p<0.05$ vs. THC

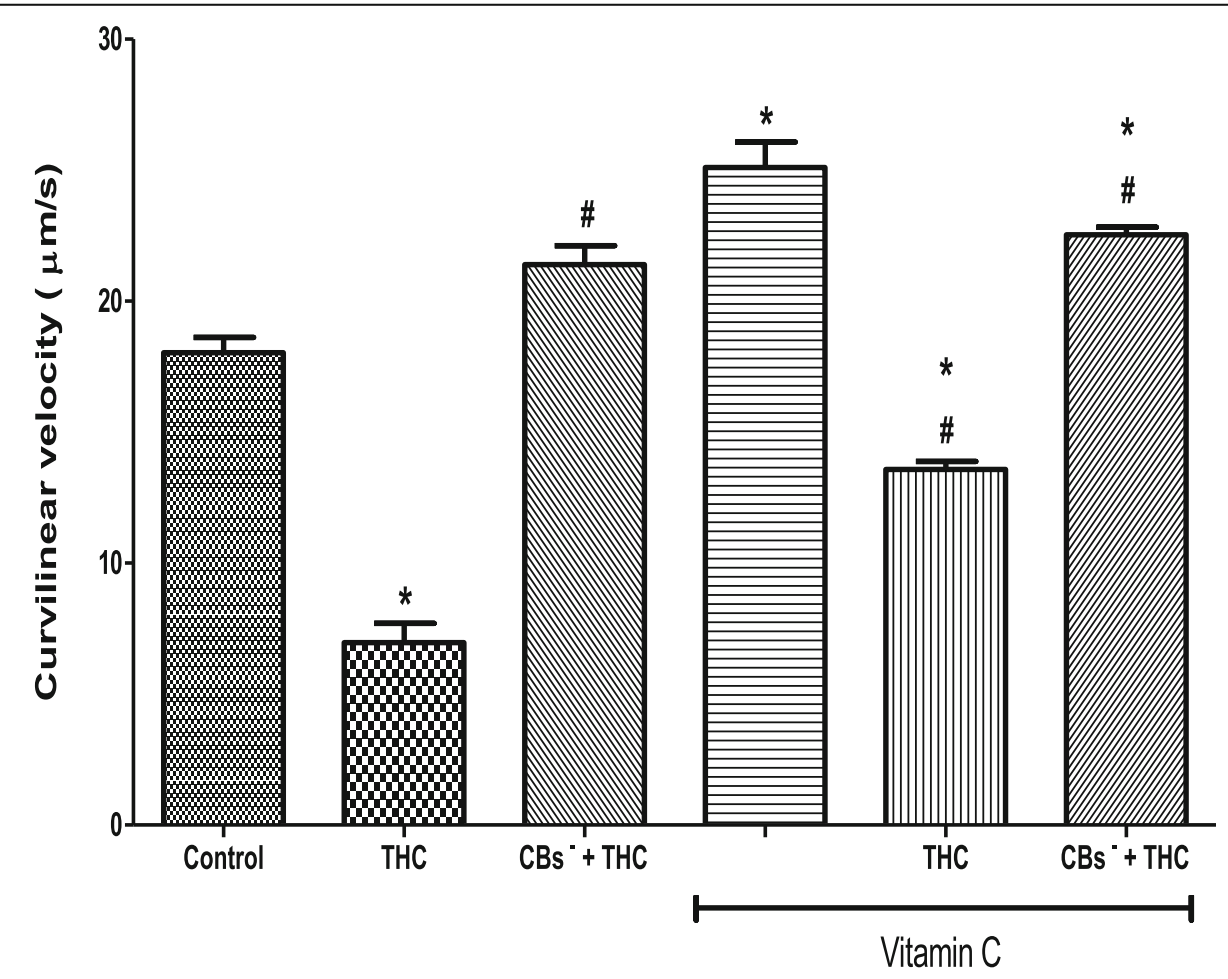

Fig. 4 Vitamin $C$ attenuated the tetrahydrocannabinol-induced reduction in the curvilinear velocity of rat spermatozoa. THC, tetrahydrocannabinol; $\mathrm{CBs}^{-}$, cannabinoid receptors' blockers; ${ }^{*} p<0.05$ vs. Control; ${ }^{*} p<0.05$ vs. THC 


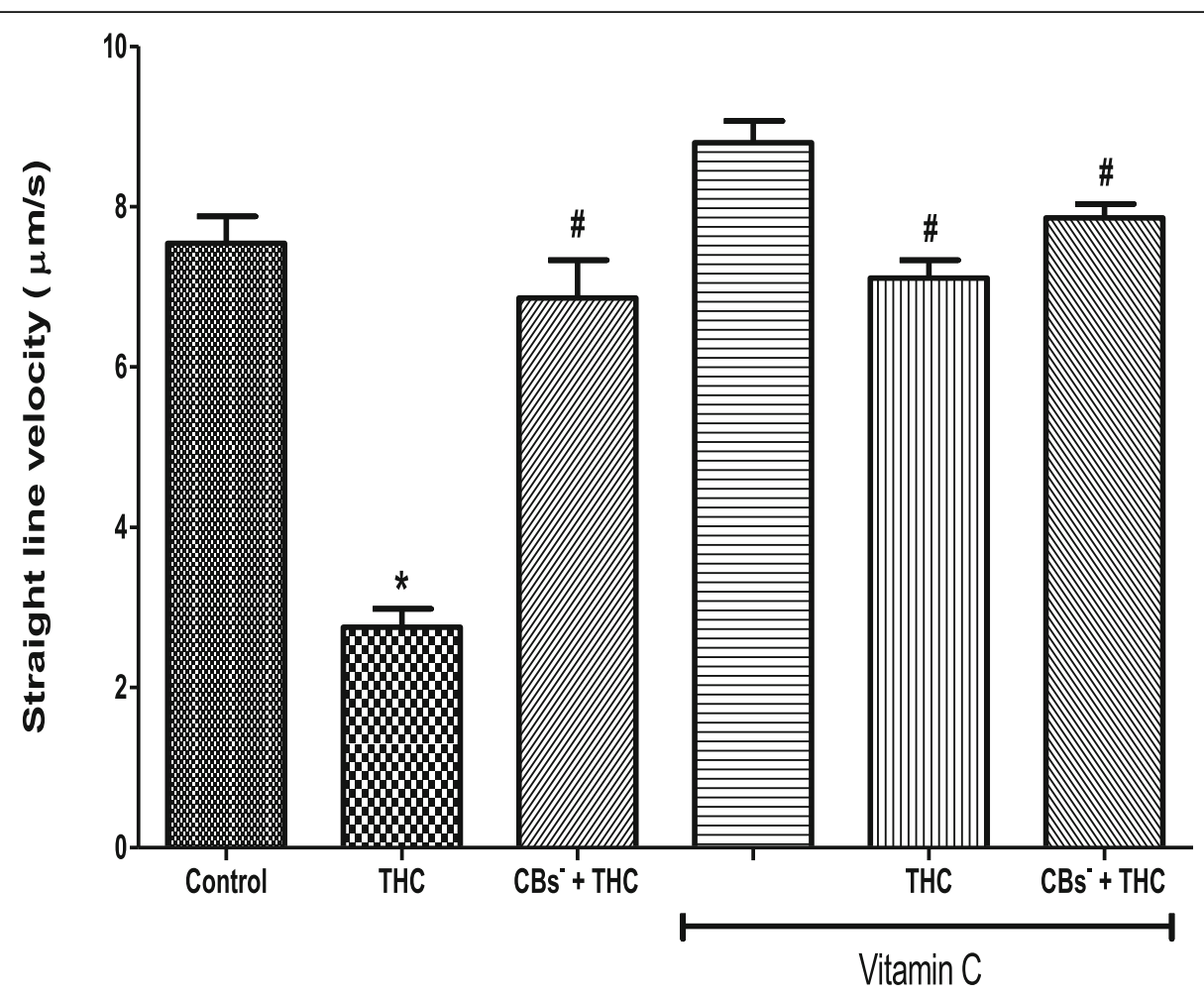

Fig. 5 Vitamin $C$ abolished the tetrahydrocannabinol-induced reduction in the straight line velocity of rat spermatozoa. THC, tetrahydrocannabinol; $\mathrm{CBs}^{-}$, cannabinoid receptors' blockers; ${ }^{*} p<0.05$ vs. Control; ${ }^{\#} p<0.05$ vs. THC

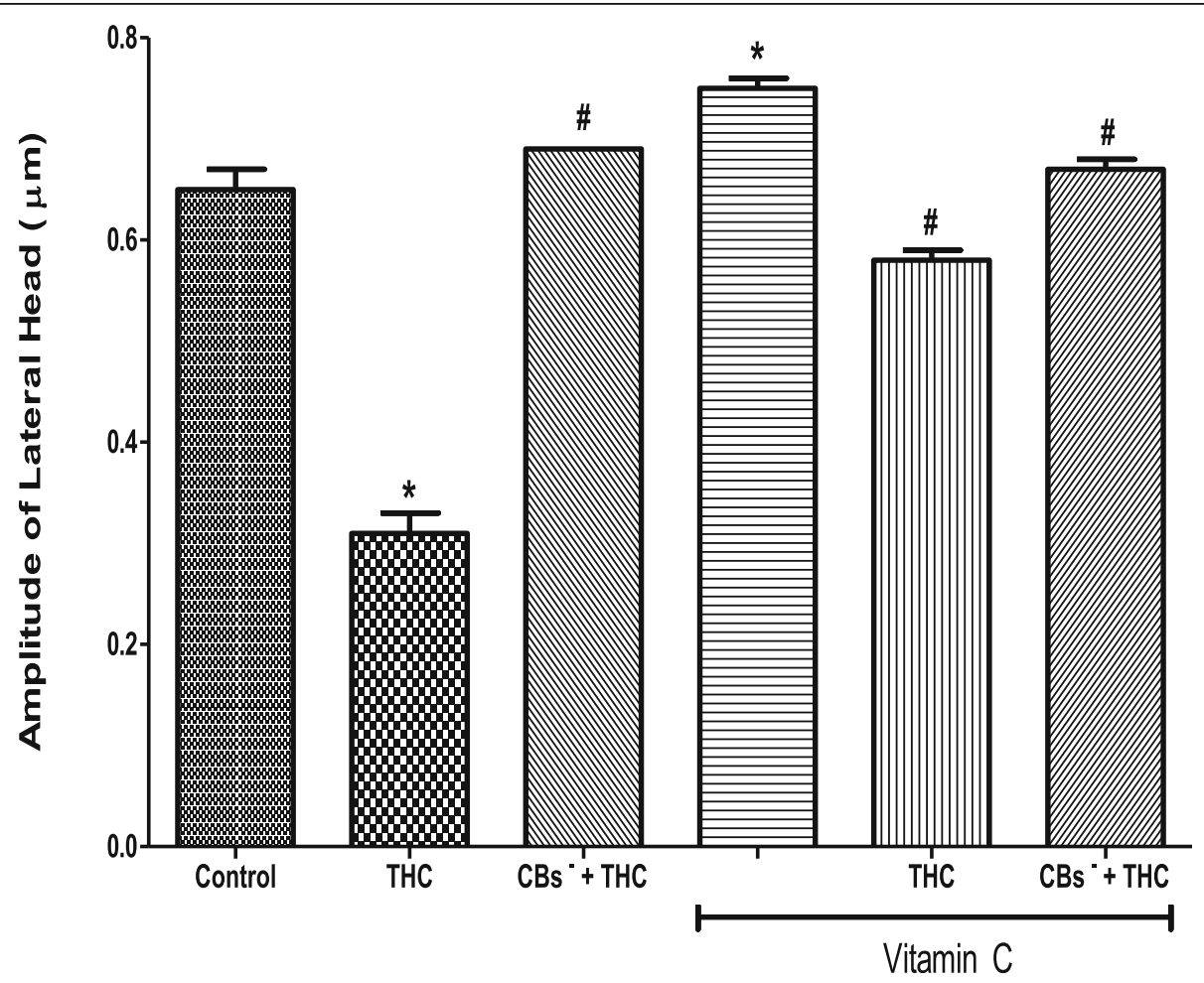

Fig. 6 Vitamin $C$ attenuated the tetrahydrocannabinol-induced reduction in the amplitude of lateral head of rat spermatozoa. THC, tetrahydrocannabinol; $\mathrm{CBs}^{-}$, cannabinoid receptors' blockers; ${ }^{*} p<0.05$ vs. Control; ${ }^{*} p<0.05$ vs. THC 
control $(2.79 \pm 0.01 \mathrm{~Hz})$. Vitamin C inhibited the THCinduced reduction in BCF $(2.60 \pm 0.01 \mathrm{~Hz})$ by maintaining it at $93 \%$ of the control value. When cannabinoid receptors 1 and 2 were blocked, vitamin $\mathrm{C}$ completely abolished the effect of THC on BCF by maintaining it at a level $(2.77 \pm 0.03 \mathrm{~Hz})$ comparable to that of control (Fig. 7).

\section{The effect of vitamin C on velocity ratios in THC-treated spermatozoa}

THC and/or vitamin C caused no significant change in the spermatozoa wobble, straightness and linearity when compared to control. THC did not also have any effect on these velocity ratios when cannabinoid receptors 1 and 2 were blocked, either in the presence or absence of vitamin C (Table 1).

\section{Prediction of progressive motility by the kinematics of spermatozoa}

Using the ROC curve, we determined if kinematics could predict the progressive motility of spermatozoa treated with THC and/or vitamin C. The curve showed that $100 \%$ of progressively motile spermatozoa had $8.76 \mu \mathrm{m}$ $\mathrm{s}^{-1}$ as VAP, $10.36 \mu \mathrm{m} \mathrm{s}^{-1}$ as VCL, $4.96 \mu \mathrm{m} \mathrm{s}^{-1}$ as VSL,
Table 1 Effect of vitamin C on velocity ratios in tetrahydrocannabinol-treated spermatozoa

\begin{tabular}{llll}
\hline Groups & $\begin{array}{l}\text { Wobble } \\
\text { (VAP/VCL, \%) }\end{array}$ & $\begin{array}{l}\text { Straightness } \\
\text { (VSL/VAP, \%) }\end{array}$ & $\begin{array}{l}\text { Linearity } \\
\text { (VSL/VCL, \%) }\end{array}$ \\
\hline Control & $76.08 \pm 2.91$ & $55.18 \pm 3.27$ & $42.01 \pm 3.13$ \\
THC & $81.45 \pm 9.23$ & $49.81 \pm 4.49$ & $40.52 \pm 5.70$ \\
CBs $^{-}+$THC & $68.64 \pm 1.43$ & $46.89 \pm 3.74$ & $32.16 \pm 2.55$ \\
Vitamin C & $71.44 \pm 1.98$ & $49.14 \pm 0.91$ & $35.07 \pm 0.39$ \\
Vitamin C+ THC & $80.96 \pm 4.01$ & $64.83 \pm 1.96^{\#}$ & $52.35 \pm 1.36^{\#}$ \\
CBs $^{-}+$THC + Vitamin C & $69.74 \pm 2.59$ & $50.15 \pm 2.04$ & $34.88 \pm 0.63$
\end{tabular}

THC tetrahydrocannabinol, $C B S^{-}$cannabinoid receptors' blockers, VSL straight line velocity, VCL curvilinear velocity, VAP average-path velocity, ${ }^{"} p<0.05$ vs. THC

$0.45 \mu \mathrm{m}$ as ALH, $1.73 \mathrm{~Hz}$ as BCF, $66.49 \%$ as wobble, and $32.46 \%$ as linearity while $100 \%$ of non-progressively motile spermatozoa had below these parameters' cut-off values (except for wobble and linearity that the specificity is $33.30 \%$ ). The velocity ratios (wobble, straightness, and linearity) had lower confidence intervals and areas under the ROC curves than velocities, ALH, and BCF. Thus, there was a very low probability that the progressively motile and non-motile spermatozoa differ in their velocity ratios (wobble, straightness and linearity), while

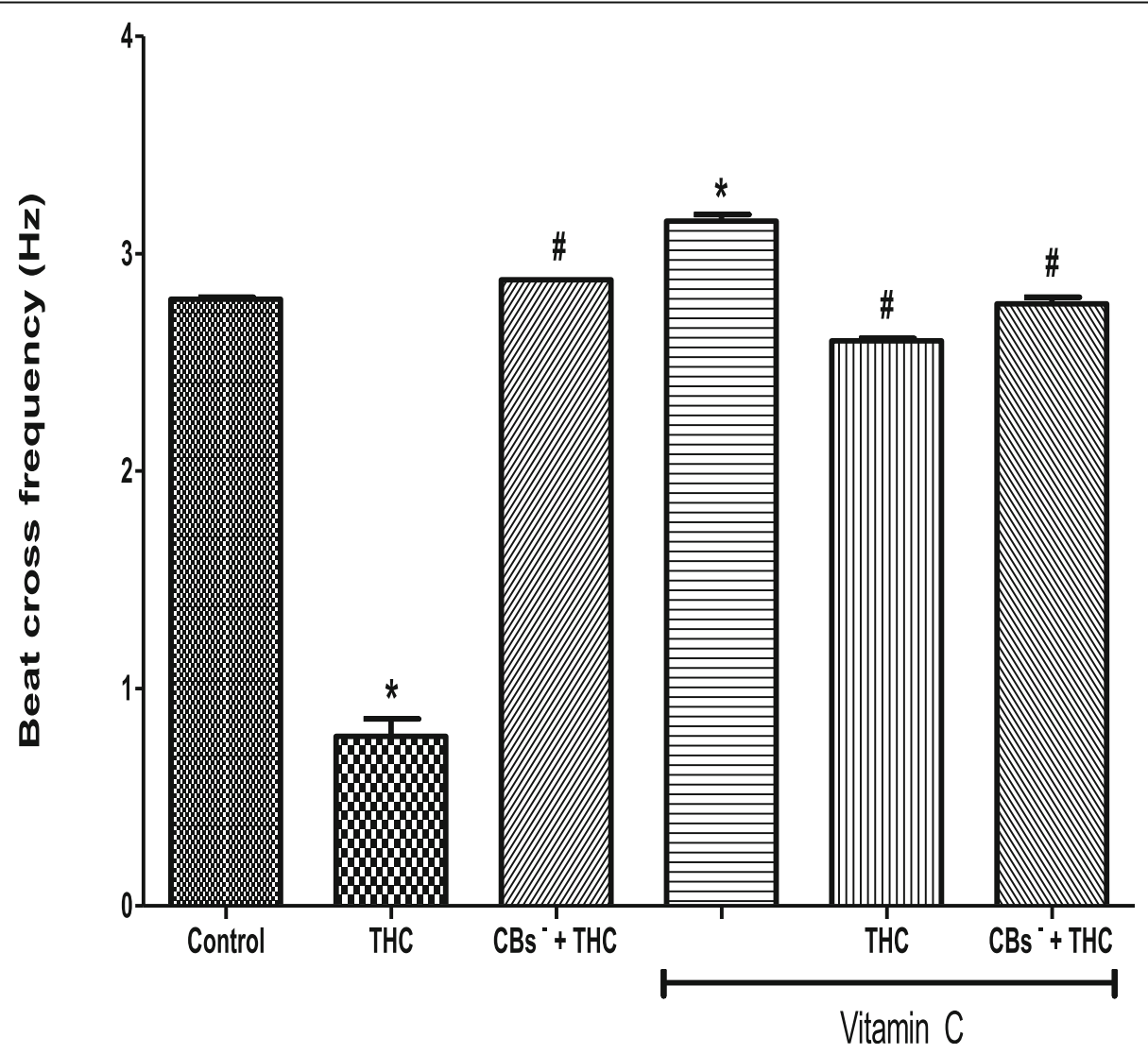

Fig. 7 Vitamin $C$ attenuated the tetrahydrocannabinol-induced reduction in the beat cross frequency of rat spermatozoa. THC, tetrahydrocannabinol; $\mathrm{CBs}^{-}$, cannabinoid receptors' blockers; ${ }^{*} p<0.05$ vs. Control; ${ }^{\#} p<0.05$ vs. THC 
there was a very high probability that they differ in their velocities (VAP, VCL, and VSL), ALH and BCF (Table 2).

\section{Discussion}

The reduction in spermatozoa motility by THC was initially reported in sea urchin by Schuel's group [14-16]. A series of studies later showed that cannabinoid receptors activation by anandamide (an endocannabinoid agonist) or THC inhibits spermatozoa functions like motility, velocities, capacitation and acrosome reaction in the frog, rat [6, 17], boar [27], and human [19, 28-31]. Furthermore, the spermatotoxic potential and the consequent anti-fertility effect of marijuana $[7,9,10]$ and its primary psychoactive cannabinoid (THC) [17] are wellknown.

Ejaculated spermatozoa capacitation process in the female reproductive tract involves membrane and metabolic modifications such as the generation of reactive oxygen species (ROS), an increase in intracellular ions and protein tyrosine phosphorylation, and changes in motility and plasma membrane fluidity [32, 33]. Events like spermatozoa binding to the zona pellucida (ZP), acrosome reaction, and oocyte fertilisation all depend on successful capacitation process [34], prevention of which will lead to fertilisation failure [35]. During this process, spermatozoa acquire a motility pattern called HAM [36] that is characterised by asymmetrical flagellar beating [37], which is needed for fast swimming and generation of enough force necessary to penetrate cumulus cells and ZP during fertilisation [38]. Because the HAM patterns of mammalian spermatozoa capacitated in-vivo and in-vitro have been reported to be similar $[39,40]$, it has been very easy for researchers to study different aspects of spermatozoa physiology by in-vitro capacitation. Our data in this study showed that THC reduced the progressive motility of spermatozoa incubated in capacitation medium, which corroborates its spermatotoxic effect.
Vitamin $\mathrm{C}$ has been previously reported to improve rat's semen parameters in-vivo [9] and ameliorate the spermatotoxicity induced by cisplatin in rats $[41,42]$ and p-dimethylaminoazobenzene in mice [43]. In a randomised controlled clinical trial that included cases after varicocele surgery, vitamin $C$ supplementation significantly increased motility and morphology but not count in infertile young adult males with low-quality spermatozoa, suggesting that it positively affects qualitative but not quantitative characteristics of semen analysis in this condition [44]. Apart from the reported improvement in spermatozoa quality in smokers by increasing vitamin $\mathrm{C}$ dose from 200 to $1000 \mathrm{mg}$ [45], another observational study on healthy, non-smoking Americans showed that vitamin C-containing diet or supplement increased spermatozoa count and motility [46]. When combined with vitamin $E$, vitamin $C$ has also been reported to enhance rabbit male fertility [47] by increasing concentration and total motile but decreasing abnormal and dead spermatozoa [47, 48]. A combination of vitamins $C$ and $\mathrm{E}$ reportedly ameliorate the oxidative stress and spermatotoxicity induced by endosulfan in rats [49].

Does vitamin $\mathrm{C}$ have spermatoprotective effect invitro? Previous reports have shown that vitamin $C$ is the most important seminal anti-oxidant, accounting for about $65 \%$ of the seminal anti-oxidant capacity, and is currently being used in-vitro to enhance spermatozoa quality in infertility clinics [50, 51]. An Egyptian study has linked smoking to decrease in seminal plasma vitamin $C$, which was shown to consequently reduce semen parameters and fertilisation potential [52]. Our doseresponse and time-course of modulation study showed that vitamin $\mathrm{C}$ increased the percentage motility of spermatozoa in a dose-dependent but not timedependent manner. For instance, $100 \mu \mathrm{M}, 1 \mathrm{mM}, 5 \mathrm{mM}$, and $10 \mathrm{mM}$, but not $10 \mu \mathrm{M}$, significantly increased the spermatozoa motility throughout the observation period when compared to the baseline. Furthermore, incubation of spermatozoa in $5 \mathrm{mM}$ of vitamin $\mathrm{C}$ solution also

Table 2 Prediction of hyper-activated motility by the kinematics of capacitated spermatozoa treated with tetrahydrocannabinol with (out) vitamin C

\begin{tabular}{llllllll}
\hline Outcomes & Predictors & Sensitivity (\%) & Specificity (\%) & Cutoff value & AUC & 95\% Cl & p-values \\
\hline Progressive motility & VAP $(\mu \mathrm{m} / \mathrm{s})$ & 100.00 & 100.00 & 8.76 & 1.000 & 1.000 to 1.000 & 0.000 \\
& VCL $(\mu \mathrm{m} / \mathrm{s})$ & 100.00 & 100.00 & 10.36 & 1.000 & 1.000 to 1.000 & 0.000 \\
& VSL $(\mu \mathrm{m} / \mathrm{s})$ & 100.00 & 100.00 & 4.96 & 1.000 & 1.000 to 1.000 & 0.000 \\
& ALH $(\mu \mathrm{m})$ & 100.00 & 100.00 & 0.45 & 1.000 & 1.000 to 1.000 & 0.000 \\
& BCF $(\mathrm{Hz})$ & 100.00 & 100.00 & 1.73 & 1.000 & 1.000 to 1.000 & 0.000 \\
& Wobble (\%) & 100.00 & 33.30 & 66.49 & 0.333 & -0.200 to 0.867 & 0.405 \\
& Straightness (\%) & 88.90 & 66.70 & 48.43 & 0.778 & 0.455 to 1.101 & 0.166 \\
& Linearity (\%) & 100.00 & 33.30 & 32.46 & 0.593 & 0.181 to 1.004 & 0.644 \\
\hline
\end{tabular}

VAP Average-path velocity, VCL Curvilinear velocity, VSL Straight-line velocity, ALH Amplitude of lateral head displacement, BCF Beat/cross frequency, AUC Area under the receiver operating characteristic curve, $\mathrm{Cl}$ Confidence interval 
increased their motility by $22 \%$ when compared to control. The vitamin $\mathrm{C}$-induced increase in spermatozoa motility was associated with an increase in VAP, VCL, VSL, ALH and BCF but decrease in straightness and linearity. These data provide pieces of evidence that vitamin $C$ increases motility by enhancing the kinematics of spermatozoa. These data are consistent with the previous report of Babaie and Sivandi [24] that also reported an improvement in the motility and kinematics of caprine spermatozoa treated with vitamin $\mathrm{C}$ in-vitro. Similar to our study, Babaie and Sivandi [24] obtained epididymal spermatozoa from adult goat testes and incubated them in the capacitation medium $\left(\mathrm{Ca}^{2+}\right.$-free Tyrode's medium, spermatozoa TALP) supplemented with $50 \mu \mathrm{g} /$ $\mathrm{ml}$ vitamin $\mathrm{C}$, after which the motion parameters were assessed using the CASA at various intervals. They also observed that vitamin $C$ increased total and progressive spermatozoa motility, VCL, VSL, linearity, ALH and BCF.

Can vitamin $\mathrm{C}$ ameliorate the THC-induced spermatotoxicity? In our previous in-vivo studies, we reported that the CS-induced spermatotoxicities (and the associated endocrine disruption and oxidative stress) were exacerbated by either vitamin $C$ or melatonin when administered separately, but ameliorated when vitamin $\mathrm{C}$ was coadministered with melatonin $[7,9,10]$. However, our most recent in-vitro study showed that melatonin attenuated THC-induced reduction in spermatozoa motility and kinematics of rat. Based on our observation that the modulatory effects of melatonin on spermatotoxicity induced by CS or THC are different in-vivo and in-vitro, we were interested to know the effect of vitamin $\mathrm{C}$ on THCinduced spermatotoxicity in-vitro. In the present in-vitro study where spermatozoa were incubated with THC and vitamin $\mathrm{C}$ in the capacitation medium, we observed for the first time that vitamin $C$ completely abolished the THC-induced reduction in progressive motility of spermatozoa by maintaining it at $94 \%$ of the control (which is not significantly different from the control level). We also observed that vitamin $\mathrm{C}$ attenuated the THC-induced reduction of VAP, VCL, ALH, and BCF but abolished the THC-induced reduction in VSL. These data provide pieces of evidence that vitamin $\mathrm{C}$ ameliorates the THCinduced spermatotoxicity, especially as regards motility and kinematics of spermatozoa. Taken together with our previous in-vivo study, it also suggests that vitamin $\mathrm{C}$ ameliorates cannabinoid-induced spermatotoxicity invitro but exacerbates it in-vivo. It is thus similar to our recent study where we reported that melatonin ameliorates cannabinoid-induced spermatotoxicity in-vitro but exacerbates it in-vivo [17].

Is there a crosstalk between vitamin $\mathrm{C}$ and cannabinoid signalling? The existence of cannabinoid receptors (CbRs) and the endocannabinoid system in mammalian spermatozoa has been well-reported [31, 53, 54]. We have reported that THC-induced reduction in the HAM of spermatozoa was abolished when both CbRs 1 and 2 were blocked, but was only attenuated when either $\mathrm{CbR}$ 1 or CbR 2 was selectively blocked. We also showed that CbR 1 contributed more than CbR 2 in THC-induced spermatotoxicity [17]. Since the involvement of both CbRs in the regulation of spermatozoa motility has been established, the current study further investigated if the lack of complete abolishment of some kinematics by vitamin $\mathrm{C}$ is associated with CbRs activation by THC in spermatozoa incubated with a combination of THC and vitamin C. We blocked both CbRs (SR141716 as $\mathrm{CB}^{-} 1$ and $A M-630$ as $C^{-}$2) and then added THC and vitamin $C$ to the capacitation medium. We observed that prior blockade of CbRs cancelled the spermatotoxic effect of THC as vitamin $\mathrm{C}$ abolished the effect of THC on VSL, ALH and BCF, and even raised the progressive motility, VAP and VCL above the control value. This shows that vitamin $\mathrm{C}$ caused more inhibition of THCinduced spermatotoxicity when CbRs were blocked and is a pointer to the fact that there is a crosstalk between vitamin $\mathrm{C}$ and cannabinoid signalling.

Is the ameliorative effect of vitamin $\mathrm{C}$ on motility related to the kinematics of spermatozoa? Across a wide range of animals like birds [55], fishes [56] and mammals [57], the competition of spermatozoa to fertilise the ovum is favoured by traits (e.g. kinematics) that promote the fertilising ability of male. To penetrate different barriers along its track, the spermatozoon requires a high flagellar BCF [58]. The VCL and ALH signify the hyperactivated motility (HAM) of spermatozoa and the highenergy state required for successful fertilisation [59] while motility and velocities of spermatozoa reflect their mitochondrial function and energy status that have been correlated with their fertility [60]. Moreover, the progressive motility of spermatozoa has been positively correlated with the VAP, VCL, VSL, ALH, BCF, straightness, and linearity but negatively correlated with wobble in bulls [57, 61, 62]. In our recent study, velocities (VAP, VCL and VSL), ALH and BCF showed strong predictive power on HAM, suggesting that these kinematics determine the response of spermatozoa capacitation-induced HAM to cannabinoids and melatonin [17]. In the present study, there was a very low probability that the progressively motile and non-motile spermatozoa differ in their velocity ratios (wobble, straightness and linearity), while there was a very high probability that they differ in their velocities (VAP, VCL, and VSL), ALH and BCF. These suggest that velocities, ALH and BCF determine the modulation of spermatozoa capacitation-induced HAM by cannabinoids and vitamin C.

Even though hydrogen peroxide is the major ROS produced in spermatozoa, a previous study has shown that $87 \%$ of infertile patients have superoxide anion [63]. 
Spermatozoa are sensitive to assault from free radicals due to the existence of high membrane polyunsaturated fatty acids and lack of capacity for DNA repair [64]. Increased ROS level has also been shown to correlate with decreased motility [65] and many structural and functional abnormalities of spermatozoa. Meanwhile, nonenzymatic antioxidants like vitamin $C$, pyruvate, vitamin $\mathrm{E}$, taurine, vitamin $\mathrm{A}$, hypotaurine, albumin, ubiquitol, urate, and enzymatic antioxidants like catalase, superoxide dismutase, and glutathione peroxidase/reductase have been reported to be contained in the seminal fluid [66], even though vitamin $C$ is considered as the major antioxidant in the testis [67]. Furthermore, the ROSinduced damage in spermatozoa has been shown to reduce with supplementation of the latter's clinical media with antioxidant [64]. Despite the physiological significance of vitamin $\mathrm{C}$ in the body, especially on spermatozoa, humans (unlike most animals) are unable to synthesise vitamin $C$, making its inclusion in diet or supplement a necessity [68]. Vitamin $C$ transporters have been reported to be expressed in the Sertoli cells, spermatocytes, spermatids, spermatozoa and the testis [69, 70]. However, our present study is limited due to our inability to establish the relationship between vitamin $C$ transporters and cannabinoid receptors as regards HAM of capacitated spermatozoa, which is worthy of consideration in a future study. Another limitation of our study is our inability to estimate the seminal ROS and antioxidant levels in all the groups, which would have enabled us to understand the relationship between spermatozoa kinematics and redox system and their modulation by vitamin $C$ and/or cannabinoid system. Notwithstanding the limitations, our study is the first to provide information on the in-vitro effect of vitamin $\mathrm{C}$ on hyperactivated motility and kinematics of capacitated spermatozoa treated with cannabinoids.

\section{Conclusion}

In conclusion, our present acute study shows that vitamin C ameliorates THC-induced reduction in spermatozoa motility in-vitro by modulation of their kinematics. Since the success rate of in-vitro fertilisation among users of CS is known to be low [71], the outcome of our present acute study is of clinical importance as it suggests that the success rate of in-vitro fertilisation among CS users could be improved by in-vitro supplementation of their spermatozoa with vitamin C. We recommend that a similar study should be conducted on human spermatozoa.

\section{Abbreviations}

THC: tetrahydrocannabinol; $\mathrm{CBs}^{-}$: cannabinoid receptors' blockers;

VAP: average path velocity; VCL: curvilinear velocity; VSL: straight-line velocity; ALH: the amplitude of lateral head; BCF: beat cross frequency; CS: Cannabis sativa; AIDS: acquired immunodeficiency syndrome; DNA: deoxyribonucleic acid; HAM: hyper-activated motility; CASA: computer-assisted sperm analyser; BWW: Biggers-Whitten-Whittingham; BSA: bovine serum albumin; DMSO: dimethyl sulphoxide; ANOVA: one-way analysis of variance; ROC: Receiver Operating Characteristic; ROS: reactive oxygen species; ZP: zona pellucida; CbRs: cannabinoid receptors

\section{Acknowledgements}

The authors acknowledge Oyeyemi Abdulwahab of Igbinedion University, Okada, who was a Ph.D. candidate in the Department of Physiology, University of Ibadan, Nigeria for permitting us to use his computer-assisted semen analyser. We also appreciate Mr. Adebowale Olabanji of Bridge Scientifik Enterprises llorin for his technical assistance.

\section{Authors' contributions}

IAA and LAO both conceived and designed the study. IAA carried out the study, interpreted the data, and drafted the manuscript. LAO supervised the study. Both authors read and approved the final manuscript to be published.

\section{Funding}

This research did not receive any specific grant from funding agencies in the public, commercial, or not-for-profit sectors.

\section{Availability of data and materials}

The datasets used and/or analysed during the current study are available from the corresponding author on reasonable request.

\section{Ethics approval and consent to participate}

All the animals were well-catered according to the criteria outlined in the 'Guide for the Care and Use of Laboratory Animals' prepared by the National Academy of Science and approved by the Ethical Research Committee of the University of Ilorin, Nigeria.

The consent to participate in the study is not applicable.

\section{Consent for publication}

Not applicable.

\section{Competing interests}

The authors declare that they have no competing interests.

\section{Author details}

'Department of Physiology, School of Medicine and Pharmacy, University of Rwanda College of Medicine and Health Sciences, Huye, Republic of Rwanda. ${ }^{2}$ Department of Physiology, College of Health Sciences, University of Ilorin, Ilorin, Kwara, Nigeria.

Received: 10 June 2020 Accepted: 30 September 2020

Published online: 24 November 2020

References

1. Abdel-Salam O. Gastric acid inhibitory and gastric protective effects of Cannabis and cannabinoids. Asian Pac J Trop Med. 2016;9(5):413-9.

2. Lynch ME. Cannabinoids in the management of chronic pain: a front line clinical perspective. J Basic Clin Physiol Pharmacol. 2016;27(3):189-91.

3. Juknat A, Kozela E, Kaushansky N, Mechoulam R, Vogel Z. Anti-inflammatory effects of the cannabidiol derivative dimethylheptyl-cannabidiol - studies in BV-2 microglia and encephalitogenic T cells. J Basic Clin Physiol Pharmacol. 2016;27(3):289-96.

4. Tzadok M, Uliel-Siboni S, Linder I, Kramer U, Epstein O, Menascu S, et al. CBD-enriched medical cannabis for intractable pediatric epilepsy: the current Israeli experience. Seizure. 2016;35:41-4.

5. Velasco G, Hernández-Tiedra S, Dávila D, Lorente M. The use of cannabinoids as anticancer agents. Prog Neuro-Psychopharmacology Biol Psychiatry. 2016:64:259-66.

6. Cobellis G, Cacciola G, Scarpa D, Meccariello R, Chianese R, Franzoni MF, et al. Endocannabinoid system in frog and rodent testis: Type-1 cannabinoid receptor and fatty acid amide hydrolase activity in male germ Cells1. Biol Reprod. 2006;75(1):82-9.

7. Alagbonsi IA, Olayaki LA, Salman TM. Melatonin and vitamin C exacerbate Cannabis sativa-induced testicular damage when administered separately but ameliorate it when combined in rats. J Basic Clin Physiol Pharmacol. 2016;27(3):277-87 
8. Gundersen TD, Jørgensen N, Andersson A-M, Bang AK, Nordkap L, Skakkebæk NE, et al. Association between use of marijuana and male reproductive hormones and semen quality: a study among 1,215 healthy young men. Am J Epidemiol. 2015;182(6):473-81.

9. Alagbonsi IA, Olayaki LA. Role of oxidative stress in Cannabis sativa -associated spermatotoxicity: evidence for ameliorative effect of combined but not separate melatonin and vitamin C. Middle East Fertil Soc J. 2017; 22(2):136-44.

10. Alagbonsi IA, Olayaki LA. Ameliorative effect of combined melatonin and vitamin C on Cannabis sativa -induced reproductive hormonal toxicity. J African Assoc Physiol Sci. 2016:4:14-24.

11. El-Habashil AA, Mousa MA, El-Eraky WI, Khalil WKB, Ahmed HH, Moad NAA Possible mechanisms for the toxic effects of marijuana smoke on the reproductive axis of male albino rats. J Appl Pharm Sci. 2013;3:S59-67.

12. Consroe P, Musty R, Rein J, Tillery W, Pertwee R. The perceived effects of smoked Cannabis on patients with multiple sclerosis. Eur Neurol. 1997;38(1): 44-8.

13. Zajicek J, Fox P, Sanders H, Wright D, Vickery J, Nunn A, et al. Cannabinoids for treatment of spasticity and other symptoms related to multiple sclerosis (CAMS study): multicentre randomised placebo-controlled trial. Lancet. 2003; 362(9395):1517-26.

14. Schuel H, Schuel R, Zimmerman AM, Zimmerman S. Cannabinoids reduce fertility of sea urchin sperm. Biochem Cell Biol. 1987;65(2):130-6.

15. Schuel H, Berkery D, Schuel R, Chang MC, Zimmerman AM, Zimmerman S. Reduction of the fertilizing capacity of sea urchin sperm by cannabinoids derived from marihuana. I. Inhibition of the acrosome reaction induced by egg jelly. Mol Reprod Dev. 1991;29(1):51-9.

16. Schuel $H$, Chang MC, Berkery D, Schuel R, Zimmerman AM, Zimmerman S. Cannabinoids inhibit fertilization in sea urchins by reducing the fertilizing capacity of sperm. Pharmacol Biochem Behav. 1991;40(3):609-15.

17. Alagbonsi IA, Olayaki LA. Melatonin attenuates $\Delta 9$-tetrahydrocannabinolinduced reduction in rat sperm motility and kinematics in-vitro. Reprod Toxicol. 2018;77:62-9.

18. Schuel H, Burkman L, Lippes J, Crickard K, Mahony MC, Giuffrida A, et al. Evidence that anandamide-signaling regulates human sperm functions required for fertilization. Mol Reprod Dev. 2002;63(3):376-87.

19. Whan LB, West MCL, McClure N, Lewis SEM. Effects of delta-9tetrahydrocannabinol, the primary psychoactive cannabinoid in marijuana, on human sperm function in vitro. Fertil Steril. 2006;85(3):653-60.

20. Agarwal A, Sekhon L. Oxidative stress and antioxidants for idiopathic oligoasthenoteratospermia: is it justified? Indian J Urol. 2011;27(1):74.

21. Talebi AR, Mangoli $E$, Nahangi $H$, Anvari M, Pourentezari M, Halvaei I. Vitamin C attenuates detrimental effects of diabetes mellitus on sperm parameters, chromatin quality and rate of apoptosis in mice. Eur J Obstet Gynecol Reprod Biol. 2014;181:32-6.

22. Cooke MS, Evans MD, Podmore ID, Herbert KE, Mistry N, Mistry P, et al. Novel repair action of vitamin C upon in vivo oxidative DNA damage. FEBS Lett. 1998:439(3):363-7.

23. Podmore ID, Griffiths HR, Herbert KE, Mistry N, Mistry P, Lunec J. Vitamin C exhibits pro-oxidant properties. Nature. 1998;392(6676):559.

24. Babaei H, Sivandi S. The effects of in vitro supplementation of capacitation medium with ascorbic acid on kinetic parameters of caprine epididymal sperm. Comp Clin Path. 2014;23(1):63-8 Available from: http://link.springer com/10.1007/s00580-012-1571-x.

25. Amoako AA, Marczylo TH, Marczylo EL, Elson J, Willets JM, Taylor AH, et al. Anandamide modulates human sperm motility: implications for men with asthenozoospermia and oligoasthenoteratozoospermia. Hum Reprod. 2013; 28(8):2058-66.

26. Charan J, Kantharia N. How to calculate sample size in animal studies? J Pharmacol Pharmacother. 2013;4(4):303 Available from: http://www. jpharmacol.com/text.asp?2013/4/4/303/119726.

27. Maccarrone M, Barboni B, Paradisi A, Bernabo N, Gasperi V, Pistilli MG, Fezza F, Lucidi P, Mattioli M. Characterization of the endocannabinoid system in boar spermatozoa and implications for sperm capacitation and acrosome reaction. J Cell Sci. 2005;118(19):4393-404.

28. Schuel H, Burkman $\amalg$. Biology of Reproduction Highlights .... Biol Reprod. 2006;74(1):1

29. Battista N, Rapino C, Di Tommaso M, Bari M, Pasquariello N, Maccarrone M. Regulation of male fertility by the endocannabinoid system. Mol Cell Endocrinol. 2008;286(1-2):S17-23.
30. Francavilla F, Battista N, Barbonetti A, Vassallo MRC, Rapino C, Antonangelo $C$, et al. Characterization of the Endocannabinoid system in human spermatozoa and involvement of transient receptor potential Vanilloid 1 receptor in their fertilizing ability. Endocrinology. 2009;150(10):4692-700.

31. Agirregoitia E, Carracedo A, Subirán N, Valdivia A, Agirregoitia N, Peralta L, et al. The CB2 cannabinoid receptor regulates human sperm cell motility. Fertil Steril. 2010;93(5):1378-87.

32. Visconti PE, Westbrook VA, Chertihin O, Demarco I, Sleight S, Diekman AB. Novel signaling pathways involved in sperm acquisition of fertilizing capacity. J Reprod Immunol. 2002;53(1-2):133-50.

33. De Jonge C. Biological basis for human capacitation. Hum Reprod Update 2005;11(3):205-14.

34. Yanagimachi R. Fertility of mammalian spermatozoa: its development and relativity. Zygote. 1994;2(4):371-2.

35. Amieux PS, McKnight GS. The essential role of Rla in the maintenance of regulated PKA activity. Ann N Y Acad Sci. 2002;968(1):75-95.

36. Goodson SG, Zhang Z, Tsuruta JK, Wang W, O'Brien DA. Classification of mouse sperm motility patterns using an automated multiclass support vector machines Model1. Biol Reprod. 2011;84(6):1207-15.

37. Demott RP, Suarez SS. Hyperactivated sperm Progress in the mouse Oviduct1. Biol Reprod. 1992:46(5):779-85.

38. Jin J, Jin N, Zheng H, Ro S, Tafolla D, Sanders KM, et al. Catsper3 and Catsper4 are essential for sperm Hyperactivated motility and male fertility in the Mouse1. Biol Reprod. 2007;77(1):37-44.

39. Katz DF, Yanagimachi R. Movement characteristics of hamster spermatozoa within the Oviduct1. Biol Reprod. 1980;22(4):759-64.

40. Katz DF, Yanagimachi R. Movement characteristics of hamster and Guinea pig spermatozoa upon attachment to the Zona Pellucida1. Biol Reprod. 1981;25(4):785-91.

41. Longchar A, Prasad SB. Biochemical changes associated with ascorbic acidcisplatin combination therapeutic efficacy and protective effect on cisplatininduced toxicity in tumor-bearing mice. Toxicol Reports. 2015;2:489-503.

42. Elballat SE. Protective effect of curcumin and vitamin C each alone and in combination on cisplatin-induced sperm abnormalities in male albino rats. J Basic Appl Zool. 2016;76:52-9.

43. Surjyo B, Anisur KB. Protective action of an anti-oxidant (L-ascorbic acid) against genotoxicity and cytotoxicity in mice during p-DAB-induced hepatocarcinogenesis. Indian J Cancer. 2004;41:72-80.

44. Cyrus A, Kabir A, Goodarzi D, Moghimi M. The effect of adjuvant vitamin C after varicocele surgery on sperm quality and quantity in infertile men: a double blind placebo controlled clinical trial. Int Braz J Urol. 2015;41(2):2308.

45. Dawson EB, Harris WA, Teter MC, Powell LC. Effect of ascorbic acid supplementation on the sperm quality of smokers** supported by HoffmanLa Roche, Inc., Nutley, New Jersey.ttpresented at the 47th annual meeting of the American fertility society, Orlando, Florida, October 21 to 24, 1991. Fertil Steril. 1992:58(5):1034-9.

46. Eskenazi B, Kidd SA, Marks AR, Sloter E, Block G, Wyrobek AJ. Antioxidant intake is associated with semen quality in healthy men. Hum Reprod. 2005; 20(4):1006-12.

47. NAJJAR BEN MAÂTOUG, Amel et al. Short communication: Influence of vitamins $C$ and $E$ on sperm motility of rabbit bucks. World Rabbit Science, [S.I.], v. 21, n. 1. 2013;45-8. Available at: https://doi.org/10.4995/wrs.2013. 1174. Accessed 02 Oct. 2020. ISSN 1989-8886.

48. Yousef M, Abdallah $G$, Kamel K. Effect of ascorbic acid and vitamin E supplementation on semen quality and biochemical parameters of male rabbits. Anim Reprod Sci. 2003:76(1-2):99-111.

49. Takhshid MA, Tavasuli AR, Heidary Y, Keshavarz M, Kargar H. Protective effect of vitamins e and $C$ on endosulfan-induced reproductive toxicity in male rats. Iran J Med Sci. 2012;37(3):173-80.

50. Song GJ, Norkus EP, Lewis V. Relationship between seminal ascorbic acid and sperm DNA integrity in infertile men. Int J Androl. 2006;29(6):569-75.

51. Colagar AH, Marzony ET. Ascorbic acid in human seminal plasma: determination and its relationship to sperm quality. J Clin Biochem Nutr. 2009:45(2):144-9.

52. Mostafa T, Tawadrous G, Roaia MMF, Amer MK, Kader RA, Aziz A. Effect of smoking on seminal plasma ascorbic acid in infertile and fertile males. Andrologia. 2006:38(6):221-4.

53. Aquila S, Guido C, Santoro A, Perrotta I, Laezza C, Bifulco M, et al. Human sperm anatomy: Ultrastructural localization of the Cannabinoid1 receptor 
and a potential role of Anandamide in sperm survival and acrosome reaction. Anat Rec Adv Integr Anat Evol Biol. 2010;293(2):298-309.

54. Amoako AA, Gebeh AK, Marczylo EL, Willets JM, Elson J, Marczylo TH, et al. Impact of reference gene selection for type 2 cannabinoid receptor gene expression studies in human spermatozoa. Andrologia. 2013;45(4):278-84.

55. Birkhead TR, Martinez JG, Burke T, Froman DP. Sperm mobility determines the outcome of sperm competition in the domestic fowl. Proc R Soc London Ser B Biol Sci. 1999;266(1430):1759-64.

56. Gage MJG, Macfariane CP, Yeates S, Ward RG, Searle JBPG. Spermatozoal traits and sperm competition in Atlantic Salmon relative sperm velocity is the primary determinant of fertilization success. Curr Biol. 2004;14(1):44-7.

57. Moore HDM, Akhondi MA. Fertilizing capacity of rat spermatozoa is correlated with decline in straight-line velocity measured by continuous computer-aided sperm analysis: Epididymal rat spermatozoa from the proximal cauda have a greater fertilizing capacity in vitro than those $\mathrm{f}$. $J$ Androl. 1996;17:50-60.

58. Katz DF, Overstreet J. Mammalian sperm movement in the secretions of the male and female genital tracts. In: ES AS, editor. Testicular development, structure and function. New York: Raven Press; 1980. p. 481-9.

59. Aitken RJ, Sutton M, Warner P, Richardson DW. Relationship between the movement characteristics of human spermatozoa and their ability to penetrate cervical mucus and zona-free hamster oocytes. Reproduction. 1985;73(2):441-9.

60. Farrell PB, Foote RH, McArdle MM, Trouern-Trend VL, Tardif AL. Media and dilution procedures tested to minimize handling effects on human, rabbit, and bull sperm for computer-assisted sperm analysis (CASA). J Androl. 1996; 17(3):293-300.

61. Gasparini C, Simmons LW, Beveridge M, Evans JP. Sperm Swimming Velocity Predicts Competitive Fertilization Success in the Green Swordtail Xiphophorus helleri. PLoS One. 2010;5(8):e12146.

62. Perumal P, Srivastava SK, Ghosh SK, Baruah KK. Computer-assisted sperm analysis of freezable and nonfreezable Mithun ( Bos frontalis ) semen. J Anim. 2014;2014:1-6.

63. Mazzilli F, Rossi T, Marchesini M, Ronconi C, Dondero F. Superoxide anion in human semen related to seminal parameters and clinical aspects. Fertil Steril. 1994;62(4):862-8 Available from: https://inkinghub.elsevier.com/ retrieve/pii/S0015028216570174.

64. Donnelly ET, O'Connell M, McClure N, Lewis SEM. Differences in nuclear DNA fragmentation and mitochondrial integrity of semen and prepared human spermatozoa. Hum Reprod. 2000;15(7):1552-61 Available from: https://academic.oup.com/humrep/article-lookup/doi/10.1093/humrep/15. 7.1552 .

65. Jedlinska-Krakowska M, Bomba G, Jakubowski K, Rotkiewicz T, Jana B, Penkowski A. Impact of oxidative stress and supplementation with vitamins E and C on testes morphology in rats. J Reprod Dev. 2006;52(2):203-9 Available from: http://joi.jlc.jst.go.jp/JST.JSTAGE/jrd/17028?from=CrossRef.

66. Kim JG, Parthasarathy S. Oxidation and the spermatozoa. Semin Reprod Endocrinol. 1998;16(4):235-9 Available from: http://www.thieme-connect.de/ DOI/DOI?10.1055/s-2007-1016283.

67. Augustine LM, Markelewicz RJ, Boekelheide K, Cherrington NJ. Xenobiotic and endobiotic transporter mRNA expression in the blood-testis barrier. Drug Metab Dispos. 2005;33(1):182-9 Available from: http://dmd. aspetjournals.org/lookup/doi/10.1124/dmd.104.001024

68. Subramanian VS, Marchant JS, Reidling JCSH. N-glycosylation is required for $\mathrm{Na}$--dependent vitamin C transporter functionality. Biochem Biophys Res Commun. 2008;374:123-7.

69. Angulo C, Castro MA, Rivas Cl, Segretain D, Maldonado R, Yañez AJ, et al. Molecular identification and functional characterization of the vitamin C transporters expressed by Sertoli cells. J Cell Physiol. 2008;217(3):708-16 Available from: http://doi.wiley.com/10.1002/jcp.21545.

70. Angulo C, Maldonado R, Pulgar E, Mancilla H, Córdova A, Villarroel F, et al. Vitamin $C$ and oxidative stress in the seminiferous epithelium. Biol Res. 2011;44(2):169-80 Available from: http://www.scielo.cl/scielo.php?script=sci_ arttext\&pid=S0716-97602011000200009\&lng=en\&nrm=iso\&tlng=en.

71. Klonoff-Cohen HS, Natarajan L, Victoria CR. A prospective study of the effects of female and male marijuana use on in vitro fertilization (IVF) and gamete intrafallopian transfer (GIFT) outcomes. Am J Obstet Gynecol. 2006; 194(2):369-76.

\section{Publisher's Note}

Springer Nature remains neutral with regard to jurisdictional claims in published maps and institutional affiliations.
Ready to submit your research? Choose BMC and benefit from:

- fast, convenient online submission

- thorough peer review by experienced researchers in your field

- rapid publication on acceptance

- support for research data, including large and complex data types

- gold Open Access which fosters wider collaboration and increased citations

- maximum visibility for your research: over $100 \mathrm{M}$ website views per year

At BMC, research is always in progress.

Learn more biomedcentral.com/submissions 